UDC: 547.993.02:595.443.8-114.5.008

\title{
BIOLOGICALLY ACTIVE PHENOL AND INDOLE DERIVATIVES OF TERRESTRIAL ARTHROPODS: ELECTROPHYSIOLOGICAL AND CHEMICAL CHARACTERISTICS
}

\section{O. M. Klyuchko}

Kavetsky Institute of Experimental Pathology, Oncology and Radiobiology, NAS of Ukraine 45, Vasylkivska St., Kyiv 03022, Ukraine e-mail: kelenaXX@ukr.net

Klyuchko O.M. Biologically active phenol and indole derivatives of terrestrial arthropods: electrophysiological and chemical characteristics. Studia Biologica, 2019: 13(2); 99-116 • DOI: https://doi. org/10.30970/sbi.1302.596

Toxins-antagonists of glutamatergic synapses were found in venoms of different terrestrial Arthrpopodae, both Insecta and Aranei. Chemical structures of some of them were described, and a majority of such substances are derivatives of phenol and indole. They are used successfully for electrophysiological investigations of membrane structures, and present review is devoted to some results of such studies that may be useful for laboratory investigations. Here, we described chemical structure of some toxins, as well as the results of electrophysiological registration of activities of different venoms and toxins of Arthropodae. Hypotheses that explain physiological effects of the substances - antagonists of glutamate receptors depending on the peculiarities of their chemical structures are suggested. The role of different sites of toxins' molecules in blocking of glutamate receptors is discussed. The information about venoms' components of Insecta family Sphecidae (Philanthus triangulum), and of some Araneidae spider species of Argiope, Araneus, Nephila genera is also presented.

Keywords: Arthropods' venoms, toxins, receptor antagonists, transmembrane electric current

Arthropods' toxins are highly specific natural substances; some of them are phenol and/or indole derivatives. Toxins-antagonists of the glutamatergic synapses are used for the electrophysiological investigations of membrane structures. Such glutamate receptors' antagonists of natural origin were also found in venoms of different terrestrial Arthrpopods, both Insecta and Aranei. Chemical structures of some of them were

(C) 2019 Klyuchko O. M. Published by the Ivan Franko National University of Lviv on behalf of Біологічні Студії / Studia Biologica. This is an Open Access article distributed under the terms of the Creative Commons Attribution License (http://www.budapestopenaccessinitiative.org/ and Creative Commons Attribution 4.0 License), which permits unrestricted reuse, distribution, and reproduction in any medium, provided the original work is properly cited.

ISSN 1996-4536 (print) • ISSN 2311-0783 (on-line) • Біологічні Студії / Studia Biologica • 2019 • Том 13/№2 • C. 99-116 
deciphered as phenol or indole derivatives. Here, we described chemical structure of the most important arthropods' toxins, as well as some results of electrophysiological studies of the biological activities of their venoms and toxins. The information about venomous components of predatory Insecta from family Sphecidae (Philanthus triangulum), and some spider species from genera Argiope, Araneus, Nephila (fam. Araneidae) are also presented. Taking into consideration these data, we proposed the hypotheses that explain physiological effects of studied substances, namely the antagonists of glutamate receptors, depending on the peculiarities of their chemical structures. Finally, the role of different sites of toxins' molecules in blocking of glutamate receptors is discussed.

Investigations of potential glutamate receptors' antagonists obtained from venoms of different terrestrial Arthropodae primarily of Argiope and Araneus genera have started actively in 1980th, and they stay promising for studying of the glutamate receptors $[16,20,29,59]$. It is known that not only spiders (Araneidae) are producers of toxins antagonists of glutamate receptors, but some other Arthropodae do that as well. A spectrum of such organisms and, respectively, their toxins are extremely wide. Brief information on the properties of venoms and toxins of the arthropods was presented in [2, 36, 39, 48-50]. Here, we provide more information on the results of experimental studies of glutamate receptors antagonists from different arthropods' venoms, as well as the results of studies of chemical structure of some toxins obtained from these venoms. The results of studying different natural toxins for the neurophysiologic purposes are well described in the monographs by P.G. Kostyuk, O.O. Krishtal, I.S. Magura, and I.V. Skok $[58,63,81]$. These investigations were continued by the representatives of scientific schools headed by the above mentioned scientists in collaboration with their foreign partners [2, 36,]. Nowadays, the results of study of specific toxins from Arthropodae (including Araneidae toxins), as well as other similar phenol and indole derivatives were applied in agriculture $[16,20,29,59]$ and in the methods of ecological monitoring of environment [38-57]. Some of these results were supported by the patents [46-57]. Our review is devoted to Arthropodae toxins' study and application [1-19, 21-37, 60-97]. Study of chemical structure of arthropods' toxins allowed to define their possible role, as well as the role of their fragments in blockage of different channel-receptors complexes (CRC) $[5,8,12,22,23,28,35,37,40]$.

Antagonists of glutamatergic synapses in venoms of different terrestrial Arthrpopods and experimental study of their biological activity. At the end of 20th century, the investigators of different countries started isolation and study of the properties of some antagonists of glutamate receptors [2, 36, 24-92]. The producers of such antagonists were found in spiders of seven species living on the territory of former Soviet Union: Agalenatea redii, Mangora acalypha, Neoskona adianta, N. cruciferoides Nuctenea folium, Zuciella caspica (Middle Asia territories of the former USSR), Araneus diademetus (Caucasus). The venoms of these spiders blocked micro-excitable postsynaptic potentials (mEPSP) and excitable post-synaptic potentials (EPSP) in locust neuromuscular junctions and potential in a final plate of the frog's muscle. The effect of that venom was irreversible, and during second application, the response was possible to restore after the antagonist was removed by "washing" (physiological solution) of the membrane subjected to the effect of the antagonist [84].

ISSN 1996-4536 (print) • ISSN 2311-0783 (on-line) • Біологічні Студії / Studia Biologica • 2019 • Том 13/№2 • С. 99-116 
The blockers with similar properties have been found in New Zealand's Araneidae venoms: Argiope trifasciata, A. aurantia, A. florida, Araneus gemma, Araneus andreusi and others [12, 28, 35]. The biologically active fractions of these venoms blocked in the reversible manner the ion currents appearing in the post-synaptic membrane of locust nerve-muscular junction after the application of glutamate [8]. The lower limits of toxins concentration that blocked glutamate-activated potentials in locusts muscle were $10^{-8}-10^{-9} \mathrm{M}$ in the experiments with glutamate ionophoretic application. For obtaining the same blocking effect in experiments with the excitation of nerve terminals, it was necessary to use an order or even higher concentrations of toxins. That fact evidenced that toxin interacts with glutamate channel-receptor complex (CRC) in the activated state, since during the glutamate application, most CRC stay in this state [8]. After washing of the toxin with a solution containing glutamate, a recovery of responses was delayed or not registered at all [8]. However, although a sensitivity of locust post-synaptic membrane was possible to recover by washing of the antagonist with normal physiological solution, there was an irreversibility of toxins' action. However, at the repeated application of toxins to the same preparation, a recovery of the membrane's sensitivity worsened [28].

Araneidae toxins affected a kinetics of excitatory postsynaptic currents. Under the influence of toxins, the time of amplitude growth decreased, but their time of amplitude falling often increased and became a biphasic one [8]. The effect of toxins depended on the potential and concentration of substances, and it depended on these variables in the experiments with arginine. For example, the blocking velocity was slowed by reducing of toxins' concentration [8, 28].

During a study of the composition of venoms' active fractions of Araneidae spiders, it was found that some of these toxins are present in different venoms. For example, the venoms of A.trifasciata, A.florida, A.aurautia, A.andreusi, A.gemma contain the polypeptide with molecular weight of $636 \mathrm{Da}$, called argiotoxin $_{636}$. Its chemical structure was shown to be identical to the argiopin (AR) previously isolated from a venom of $A$. lobata by Dr. E.V. Grishin [28, 35]. A study of toxins from N. clavata, A. lobata was pioneering, and a study of antagonists from other Arthropodae venoms is in progress [2, 22, 23, 36].

The blocking properties of the argiotoxin $_{636}$ were similar to such properties of the argiopin. The results of studying of glutamate-activated single channels in locusts [28, 35] and synaptic transmission in rats' hippocampal slices [6] demonstrated that argioxin blocked the glutamate receptors in the post-synaptic membranes in a reversible manner. The argioxin was used in concentrations of $10^{-8}-10^{-9} \mathrm{M}$. The effect of the toxin was dose-dependent at concentrations of $10^{-4}-10^{-9} \mathrm{M}$ and $2.5 \cdot 10^{-8}-7.5 \cdot 10^{-9} \mathrm{M}$ for two series of experiments. In those experiments, the argioxin blocked both kainat- and quisqualatesensitive receptors. In slices of rat's hippocampus, the argiotoxin did not influence GABA-induced inhibition or aspartate-caused spikes which proved that argiotoxin does not interact with GABA or NMDA receptors [6].

There are numerous data on blocking properties of the argioxin in experiments aimed at study of single glutamate-activated channels. During a study of kinetics of toxin's action, three types of channels were registered [35]. The first type was characterized by a decrease of probability and frequency of channels opening, an increase of time of their life in a closed state, and practically unchanged (comparing to control) time of life in the open state. For a second type of channels, a further decrease of probability and frequency of channels' opening was registered, a further increase in time of life in

ISSN 1996-4536 (print) • ISSN 2311-0783 (on-line) • Біологічні Студії / Studia Biologica • 2019 • Том 13/№2 • C. 99-116 
a closed state, and a reducing of the life time in an open state. For the third type, channels opening almost did not happen. With an increase of toxin's concentration or an increase of an exposure with constant concentration, the types of channels could be arranged in the following manner: type $1 \rightarrow$ type $2 \rightarrow$ type 3 .

It was demonstrated that similar to the argiopin, the argiotoxin interacts mainly with open channels [35]. However, it can also be bound with closed channel, and this initiate a described sequence of processes. After binding with closed channel, the toxin allosterically positively modulates binding of the glutamate with the complex. That increased a probability of channel opening and, thus, its subsequent blockage by a second argioxin molecule. The following blocking scheme was proposed by Jackson [28]:

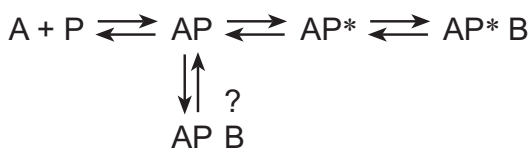

where $\mathrm{A}$ is an activating molecule of the agonist, $\mathrm{P}, \mathrm{P}^{*}$ are the receptors that correlated with closed and open state of the channel, and B is a molecule of the antagonist.

Such scheme of blocking was confirmed by speculations that have been done on a basis of data obtained in the experiments on blocking of single channels. A probability of the effect of toxin binding to the receptor with a site of the glutamate binding is enough low. However, more realistic is a scenario in which the toxin interacts first on the surface of the membrane with lipids or glycocalyx, possibly, being accumulated, and then influences the receptor [28].

There is a high amount of free glutamate found in Araneidae venoms, that can reach concentrations of 130-425 mM [17]. This glutamate might play a role in the activation of those glutamates CRC that were inactive previously followed by interaction with the argiotoxin [17].

Components of venom of Philanthus triangulum - antagonists of glutamate receptors. Araneidae are not unique for Arthropodae species that are producers of toxins-antagonists of the glutamate receptors. The phylantotoxins from venom of the predatory $P$. Triangulum insect possess similar properties as other known antagonists of the glutamate receptors [35, 77, 96]. Four toxins - alpha, beta, gamma, and delta-phylanto-toxins (PTX) [37] have been purified from the venom of Philanthus triangulum and identified; then, the fifth one was detected [8]. Chemical structure of one of them was studied that is the $\alpha$-phylantotoxin with a molecular weight of $433 \mathrm{Da}$ that interacts with the glutamate receptors (Fig. 1) [28]. Its molecule has common features with spider toxins described above. It is a polyamine coupled with the oxyphenol.

A similarity with Araneidae toxins has been also found in the action of PTX toxins toward the glutamate receptors. Delta-PTX (molecular weight of about $700 \mathrm{Da}$ ) blocked postsynaptic excitatory currents and glutamate-induced depolarization in the nervemuscular junction of the locust at concentrations of $10^{-6}-10^{-7} \mathrm{M}$ [8]. Besides, it reduced an amplitude and reduced the time of miniature potentials decrease recorded extracellularly [35]. A study of single channels in the locusts muscle showed that delta-PTX blocked glutamate channel-receptor complexes in the activated state. Blocking both integral venom and delta- PTX had a reversible effect. However, unlike the argioxin, a recovery of responses was faster if there was an agonist in the washing solution and,

ISSN 1996-4536 (print) • ISSN 2311-0783 (on-line) • Біологічні Студії / Studia Biologica • 2019 • Том 13/№2 • С. 99-116 
thus, the glutamate receptors were activated [8]. The delta-PTX also demonstrated a presynaptic action by inhibiting of the re-uptake of glutamate [37]. That effect was similar to the action of JSTX in the experiments with glutamate re-uptake by rats' synaptosomes $[75,76]$.

1.<smiles></smiles>

2.

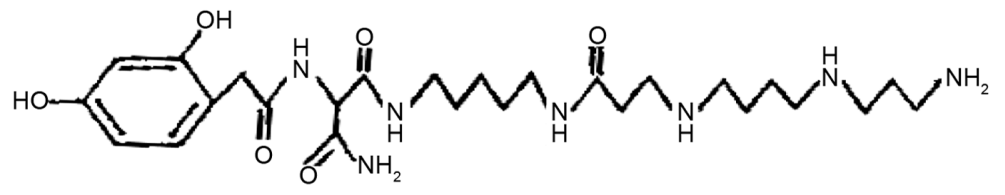

3.

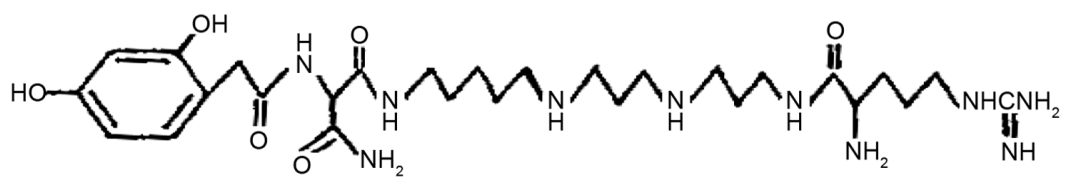

4.

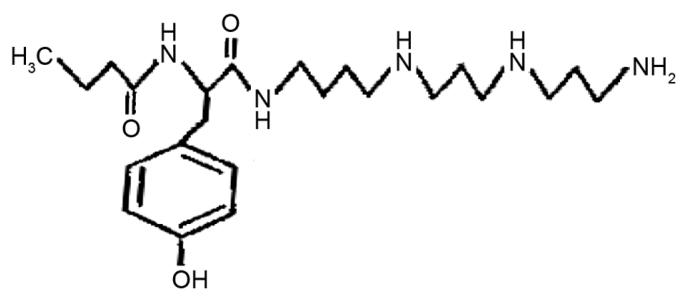

Fig. 1. Chemical structure of toxins of the arthropods: 1 - JSTX-3; 2 - NSTX-3; 3 - argiopin AR; 4 - PTX 433 $[23,40]$

Рис. 1. Хімічні структури токсинів членистоногих: 1 - JSTX-3; 2 - NSTX-3; 3 - аргіопін AR; 4 - PTX 433 $[23,40]$

The polyamine beta-PTX toxin with a molecular weight of 243 Da was also studied. This toxin inhibited glutamate postsynaptic potentials in the nerve-muscular junctions of the locusts, but its effect was weaker than that of delta-PTX [37]. The action of beta-PTX was a reverse one: the amplitude of the EPSP was restored when the toxin was washed out by the physiological solution. A degree of blockage depended on the concentration of beta-PTX. During electrical stimulation of the neuromuscular preparation, the effect depended on frequency of stimulation: in the interval of 5-20 s between impulses, the effect of blocking increased with an increase of frequency. These experiments, as well as experiments using concanavalin A, demonstrated that beta-PTX influenced desensitization of the glutamate receptor and increased a duration of desensitization period [37]. Experiments conducted on single channels have shown that beta-PTX binds to the activated glutamate receptor [37].

It should be noted that the insufficiently well-purified preparation of $P$. triangulum venom caused a weak depolarization of the post-synaptic membrane in the nerve-muscular junctions of the locusts [37]. 
Study of molecular structures of glutamate receptors' antagonists obtained from Araneidae venoms. This issue has been briefly described in our previous studies $[2,36,38-57]$. Chemical, biochemical and electrophysiological characterization of the venoms and toxins from the Arthropods have been also carried out. An improvement of the methods of isolation of the individual chemical substances from the venoms permitted in 1990th to define the molecular weight and chemical structure of some toxins. Until 1988, three most important for practical use and best studied Araneidae toxins were obtained. They are JSTX-3, NSTX-3, and argiopin.

Methods of purification of venoms and toxins from Nephila spiders. In 1986, the venoms were isolated from $N$. clavata and $N$. maculata and used for purification of toxins [5]. The venomous spiders' glands were homogenized in $60 \%$ acetonitrile and the homogenate was centrifuged for $5 \mathrm{~min}$ at 3,000 rpm. The supernatant was subjected to a reverse phase high-performance liquid chromatography (HPLC) using the octadecylsilane column (Toyo Sods, ODS TSK-120T, $4.6 \times 250 \mathrm{mM}$ ) in $0.02 \% \mathrm{HCl}$ and acetonitrile gradient concentration $0-50 \%$ during 30 min with elution rate of $0.5 \mathrm{~mL} / \mathrm{min}$. The venom from $N$. clavata contained four components possesing toxic properties - JSTX-1, JSTX-2, JSTX3 , and JSTX-4. The venom of $N$. maculata contained three such components - NSTX-1, NSTX-2, NSTX-3. JSTX-3 toxin was the main biologically active element of $N$. clavata venom, and its concentration in the venom was the highest [5]. The chemical formula of this toxin is presented in Fig. 1. Its molecule consists of the 2,4-dihydroxyphenylacetateasparagine coupled to asparagine, and through it to the polyamine [5, 28]. In the JSTX-4 molecule, the argiopin is coupled to JSTX-2 with a peptide link (Fig. 2, 3) [5]. Separate toxic components differ between themselves by their polyamines' structure (see Table):

Toxins from $N$. clavata and their chemical structure

Токсини з $\boldsymbol{N}$. clavata і їхня хімічна структура

\begin{tabular}{l|c}
\multicolumn{1}{c}{ Chemical structure } & Toxin \\
$-\left(\mathrm{CH}_{2}\right)_{3} \mathrm{NH}\left(\mathrm{CH}_{2}\right)_{3} \mathrm{NH}_{2}$ & JSTX-3 \\
$-\left(\mathrm{CH}_{2}\right)_{3} \mathrm{NH}\left(\mathrm{CH}_{2}\right)_{4} \mathrm{NH}$ & JSTX-2 \\
$-\left(\mathrm{CH}_{2}\right)_{3} \mathrm{NH}\left(\mathrm{CH}_{2}\right)_{4} \mathrm{NH}-\mathrm{Arg}$ & JSTX-4
\end{tabular}

NSTX-3 is the main active agent in N. maculata venom (Fig. 1). It is 2,4-dihydroxyphenylacetate-asparagine (arginylcadaverno-beta-alanyl) cadaverin that is very similar to JSTX-3 (Fig. 1). According to mass spectroscopic investigations, its molecular weight is $665 \mathrm{Da}$ [5]. N. clavata venoms slightly differ in their physiological action of various fractions [70,71]. Effects of some of them were reversible, while the others, for example, JSTX-3 acts irreversibly. Poorly purified JSTX-3 were stored in frozen state since they changed their properties unpredictably. At the beginning, they acted irreversibly, then with time, in electrophysiological experiments it was possible to remove its molecules from the cell membranes [70, 71].

In 1987, JSTX-3 toxin and four its analogs were synthesized in Japan. The analogs had different polyamines' structures, and all of them blocked the glutamate receptors [26]. In 1987, NSTX-3 toxin was also synthesized [87].

Study of chemical structure of the toxins obtained from A. lobata. The argiopin is the main active component of $A$. lobata venom (Fig. 1), and the concentration of AR was the highest in this venom [12]. Ability of $A$. lobata venom, mostly the argiopin, to block

ISSN 1996-4536 (print) • ISSN 2311-0783 (on-line) • Біологічні Студії / Studia Biologica • 2019 • Том 13/№2 • С. 99-116 
the glutamate receptors were determined [61, 62]. T. Budd et al. [12] showed that the argiopin is the main active component of $A$. lobata venom, and its concentration there was the highest. The molecular weight of AR in the obtained active substance was $646 \mathrm{Da}$. Its chemical structure was defined (Fig. 1). It is a 2,4-dihydroxyphenylacetateasparagine that is linked through a polyamine with the terminal arginine.

There are publications devoted to the isolation of fractions of the $A$. lobata venom containing toxins of different types of actions. E.V. Grishin et al. elaborated the method of obtaining the toxin from that venom $[22,23]$. $0.3 \%$ toxin was sedimented from a water solution using $60 \%$ ethanol. That sediment was separated by centrifuging during 10 min at 5,000 rpm. The supernatant was concentrated and analyzed using a reverse phase HPLC on the column $\left(22.7 \times 250 \mathrm{~mm}\right.$, Zorbax $\left.\mathrm{C}_{8}\right)$ in $0.1 \%$ trifluoroacetic acid in acetonitrile gradient $(0-15 \%)$ during $75 \mathrm{~min}$ with the elution rate of $10 \mathrm{~mL} / \mathrm{min}$. The molecular weight of purified toxin obtained using this method was near $1 \%$ of initial weight of the venom; all other venom fractions (substances) were removed [22, 23].

In addition to the argiopin, at least nine compounds have been isolated from A. Iobata venom (Fig. 2), and their biological activity was found to be similar to that of the argiopin. Like the argiopin, they were isolated by the HPLC [22, 23], but from other fractions of the venom (Fig. 3). The argiopin was detected in fraction 1. Fractions 3, $7-0$ were

1 .

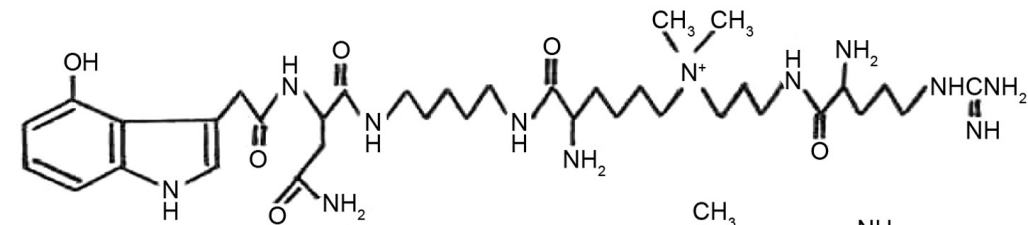

2.

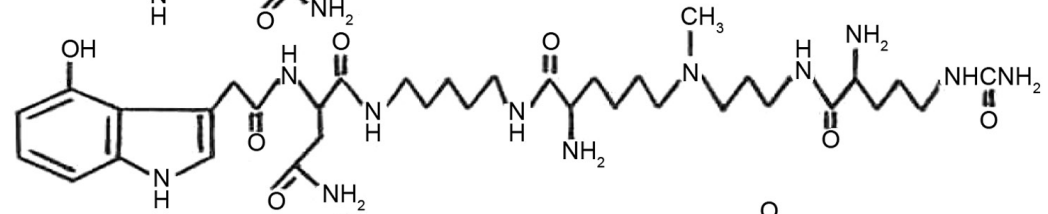

3.

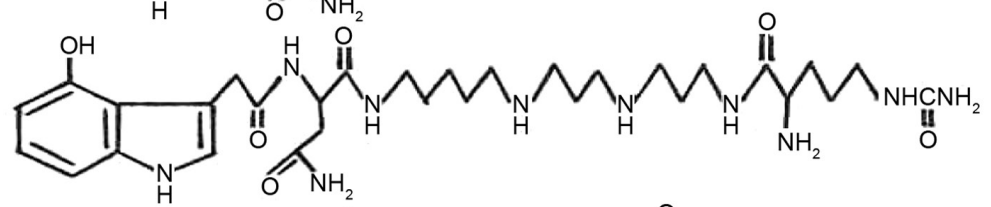

4.

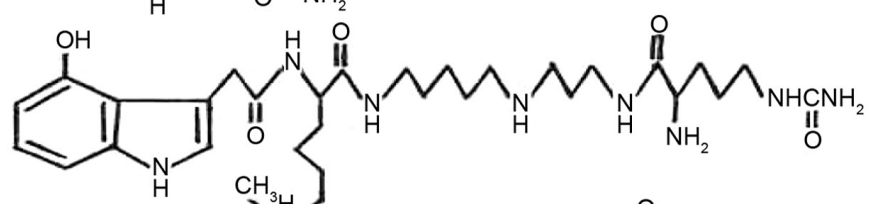

5.

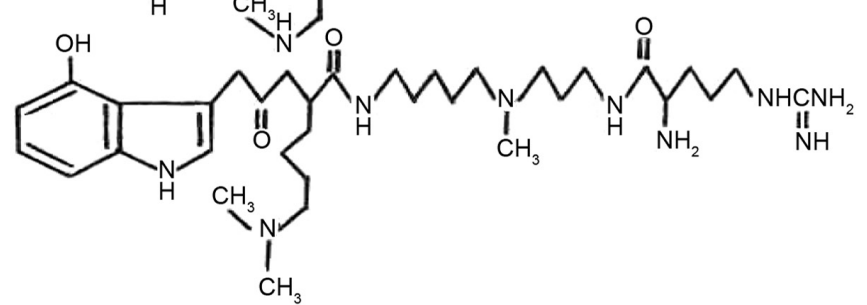

Fig. 2. Chemical structure of toxins from the argiopinins' family - ARN $[23,40]$

Рис. 2. Хімічна структура токсинів із родини аргіопінінів - ARN [23, 40] 
shown to be the individual compounds. Other components were isolated using a rechromatography of the fractions 4-6 and 10 using a column with a reverse phase in similar conditions. Further, chemical structures of all isolated toxins were studied in details [22, 23]. These substances are homologous according to their chemical structure and contain the chromophore group in their molecule (phenol or indole, asparagine (with a few exceptions), and polyamines of different lengths). According to the results of UV-spectroscopy, all components of the venom were separated into three types: argiopin, argiopinins and pseudoargiopinins (Fig. 1, 2). Thus, argiopin contains phenolacetic acid, argiopinins - dihydroxyindolacetic acid, and pseudoaryhopinins - indolacetic acid. In some compounds, the asparagine may be replaced by a modified lysine (Fig. 1, 2). The aliphatic polyamines whose length and structure are different for specific compounds, is a necessary component of each toxin. Finally, each of these substances, except the pseudoargiopinin-3, contains the arginine or its residue with a free $\alpha$-amino group [22, 23].

In 1986, E.A. Elin et al. obtained a synthetic argiopin. Such synthetic argiopin also passessed an ability to block the glutamate receptors [18].

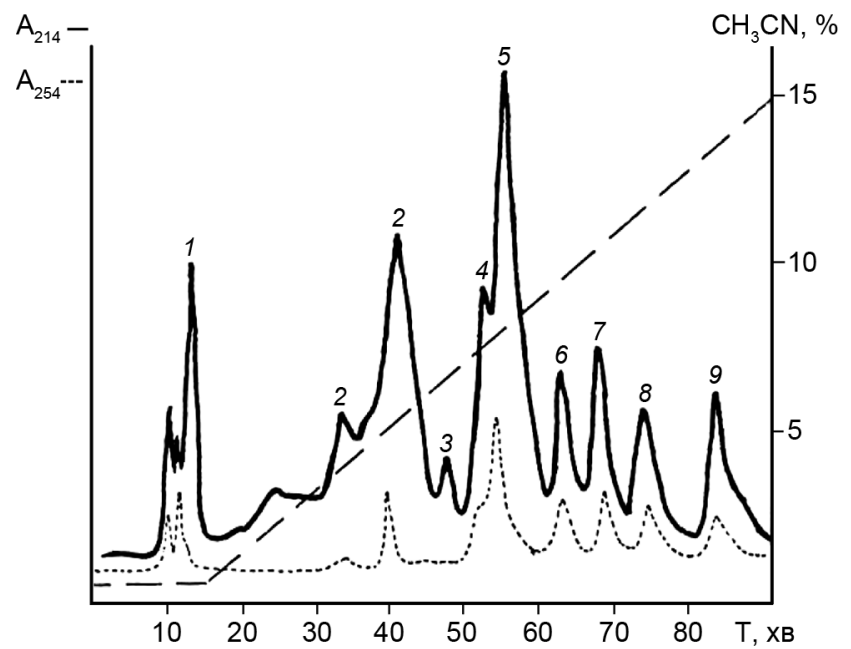

Fig. 3. Profile of separation of components of $A$. lobata venom $[22,23]$. The separation was conducted by means of HPLC on the column $(22.5 \times 250 \mathrm{~mm})$ filled with TSK ODS-120T in $0.1 \%$ trifluoroacetic acid in a gradient of acetonitrile concentration with the elution rate of $10 \mathrm{ml} / \mathrm{min}$

Рис. 3. Профріль фрракціонування компонентів отрути A. lobata [22, 23]. Розділення виконували за допомогою високоефективної рідинної хроматографрії (верх) на колонці $(22,5 \times 250$ мм), наповненій TSK ODS-120T, у 0,1\% трифртороцтовій кислоті у градієнті концентрації ацетонітрилу за швидкості елюції 10 мл/хв

Components of venoms obtained from other spiders - Argiope and Araneus. It was demonstrated that active fractions isolated from the venoms of spiders-Arachnids of American continent were similar from the point of view of their physiological properties. Besides, their action was similar to the action of active fractions of $A$. lobata toward the glutamatergic synapses $[12,28]$. The composition of the venoms from $A$. trifasciata, A. gemma, A. florida was studied. In general, methods of isolation and purification of toxins from these spiders' venoms are similar to methods developed previously for other 
toxins [5, 22, 23]. Isolation was carried out using a reverse phase HPLC [12]. Then the active fraction was studied after the re-chromatography on the $\mathrm{C}_{18}$ column with the elution rate of $2 \mathrm{ml} / \mathrm{min}$ in $0.08 \%$ solution of trifluoroacetic acid $(5 \mathrm{~min})$, and then in the acetonitrile gradient for $15 \mathrm{~min}$ in $4 \%$ solution and during next $10 \mathrm{~min}$ - in its $10 \%$ solution.

A number of active fractions was obtained and purified from the venoms of the abovementioned Araneidae. The results of studying chemical structure of toxins from such Araneidae venoms demonstrated that they contained the same substance named the argiotoxin, whose molecular weight was $636 \mathrm{Da}$. According to the results of the UV spectroscopy, their chemical structure is the same as structure of the argiopins. It was proved that active fraction of the venoms of numerous Araneidae is the argiopin, or the $\operatorname{argioxin}_{636}[12,28]$.

In addition to argioxin $_{636}$, other toxins have been obtained from the venoms of $A$. trifasciata and $A$. florida. Their chemical structures are homologous and might be sub-divided into two families. The first family contains the phenolic derivatives, and this family of toxins includes the argioxin $_{636}$ and its methylene derivatives with a molecular weight of $622,650,480,466,637,678,720 \mathrm{Da}$. While the second family of toxins includes the indolyl derivatives of similar structure having another chromophore group. In A. trifasciata, the main active agent is not the $\operatorname{argioxin}_{636}$, and principal toxin of this family is a peptide with a molecular weight of $659 \mathrm{Da}$. Its homologues have the molecular weight of $673,645,503,517 \mathrm{Da}$, respectively [12].

A contribution of each of these substances to total toxic effect of venoms is different. According to the biological activity, all substances within this family can be arranged in the following order (noted in the molecular weight) [12]:

1st family: $636 \rightarrow 622 \rightarrow 650 \rightarrow 480 \rightarrow 466 \rightarrow 637 \rightarrow 678 \rightarrow 720$

2nd family: $659 \rightarrow 673 \rightarrow 503 \rightarrow 517$

The venoms of various spiders' species differ according to a quantitative composition of their components. For example, in A. florida, concentration of the $\operatorname{argioxin}_{673}$ is the highest among toxins of the 2nd family [28]. The argiopin $_{659}$ (2nd family) according to the described properties coincides with the toxin which Jackson isolated from $A$. aurantia that irreversibly blocked a transmission between the cochlear nerve and the cochlear nucleus of birds [28].

As one can see from Fig. 1 and 2, chemical structure of the antagonists of the glutamatergic synapses isolated from the venoms of various Araneidae have many common features. All of them contain: 1 - aromatic group (phenolacetic or indolacetic), 2 asparagine or modified lysine, 3 - aliphatic polyamine of different lengths, 4 - many of them have N-terminal arginine [5, 12, 22, 23, 28].

Abovementioned toxins form two families depending on the aromatic groups which they contain. The family of the phenolacetic acid derivatives contains the most widespread and investigated toxins - the argiopin $\left(\operatorname{argioxin}_{636}\right)$, JSTX-3, NSTX-3 [28], while the family of the indolylacetic acid derivatives is less studied and contains a number of toxins from A. lobata (argiopinins, pseudoargiopinins), A. gemma, A. trifasciata and other Araneidae [12, 22, 23].

Organisms of Araneidae contain the same set of toxic substances as their venoms. Difference between these venoms from various species is the absence or presence of separate components, as well as a quantitative correlation of these components. Based on these differences in chemical composition, various venoms possess different physiological properties [12].

ISSN 1996-4536 (print) • ISSN 2311-0783 (on-line) • Біологічні Студії / Studia Biologica • 2019 • Том 13/№2 • C. 99-116 
Role of different sites of toxins' molecules in blocking the glutamate receptors. A contribution of various sites of toxin molecules into the effect of blocking the glutamate receptors is different. The role of each of these fragments and mechanisms of their interaction with the receptor are the points of interest. Most researchers suppose that the aromatic groups (residues of phenol- or indolacetic acids) play the main role in the interaction of toxins with the receptors, because these fragments are obvious part of each toxin. There are results in favor of this point of view $[75,76]$. The effects of JSTX-3 and its two fragments - 2,4-dihydroxyphenylacetate-asparagine (DHPhA-Asp) and 2,4-dihydroxyphenylacetate-asparagine (DHPhA) - on binding of marked glutamate to synaptic membranes of rat brain were investigated. All three compounds blocked the binding in a dose-dependent manner. Their effects differed in that the first two substances demonstrate the same effect in approximately the same quantities, and the DHPhA was necessary about 3-5 times more for this. A complete inhibition of binding was reached at $0.33 \mathrm{mM}$ DHPhA. The 2.5 DHFU and 3.4 DHFUs isomers also suppressed binding of the glutamate. In the control experiments, L-glutamate was substituted effectively with diethyl ether of glutamic acid, a glutamate receptor antagonist $[75$, 76]. Araneidae venoms contain DHPhA in its free state, and it is possible that in natural conditions these molecules also participate in blocking the receptors [17].

In other studies of these authors, a difference in properties of JSTX-3 and DHPhAAsp was registered [76]. It was found that JSTX-3 and DHPhA-Asp act in different way on sodium-dependent and sodium-independent seizure of glutamate by the synaptosomes of the rat brain membrane. Equal concentrations of JSTX-3 and DHPhA-Asp depressed in equal rates sodium-independent binding of glutamate (for different concentrations of the toxins). DHPhA-Asp was significantly less effective than JSTX-3 in blocking of sodium-dependent binding: to achieve the same level of blockage, the DHPhA-Asp concentration should be 10-15 times higher than concentration of the JSTX-3.

The role of polyamine in the effects of toxins was demonstrated in experiments on blocking of the excitable postsynaptic potential (EPSP) by various JSTX-3 analogues [26]. All analogues contained DHPhA-Asp combined with the polyamines of different length, but they were shorter than a one in the JSTX-3. The extension of the polyamine chain was followed by a formation of more stable toxin-receptor complex, and if, under the action of analogue with the shortest chain, the amplitude of the EPSP was restored with compound removing, then the action of JSTX-3 became practically the irreversible.

When properties of the $\operatorname{argioxin}_{636}$ analogues (argiopin) were studied, the role of $\mathrm{N}$-terminal arginine in blocking was demonstrated. The modification of the end of this molecule led to a complete loss of its activity [12].

The $\mathrm{RTX}_{433}$ molecule from $P$. triangulum toxin is very similar to Araneidae toxins. It also consists of oxyphenol connected with the polyamine. However, its polyamine does not contain asparagine or arginine. The $\mathrm{RTX}_{433}$ molecule is an effective blocker of the glutamate receptors with properties that are close to properties of Araneidae toxins. Thus, it might be expected that phylantotoxins can be also used for studying the glutamate receptor along with families of toxins from Araneidae [28].

A number of publications were devoted to a study of the molecular mechanisms of toxins' interaction of with the receptors. A protein named GBP was obtained from synaptic membranes that was able to bind glutamate $[67,68]$. It was demonstrated that the

ISSN 1996-4536 (print) • ISSN 2311-0783 (on-line) • Біологічні Студії / Studia Biologica • 2019 • Том 13/№2 • С. 99-116 
glutamate binding to this protein was inhibited by the reagents of the FeS groups $\mathrm{NaN}_{3}, \mathrm{KCN}$, chelating agents like the o-phenanthroline. Therefore, it was suggested that the membrane glutamate binding protein is a glycoproteide with FeS group at the site of ligand binding, and the spider toxins $A$. gemma. A. aurantia, N. arabesca acted on the GBP in the same way as the reagents acted on the FeS groups. This may evidence that toxins interact with the same prosthetic group [67, 68].

Subsequently, a qualitative analysis of the reaction of toxins binding with the FeS groups was carried out. The reagent on the $\mathrm{FeCl}_{3}$ phenols that contacts with it gives a dense green color of the solution [82]. The same change in color appeared when $\mathrm{FeCl}_{3}$ was added to JSTX-3 solutions $\left(\lambda_{\max }=630 \mathrm{~nm}\right)$, and it disappeared when EDTA was added [97]. No other metal ions gave such coloration at contact with phenols or JSTX-3 it was much lighter in reactions with $\mathrm{Hg}^{2+}, \mathrm{Cu}^{2+}, \mathrm{Ce}^{3+}, \mathrm{Ce}^{4+}$. An existence of such specific reaction between the $\mathrm{Fe}^{3+}$ ions and JSTX-3 permitted an assumption that in a result of their interaction appears the chelating complex with development of green color of solution [97]. A schematic representation of such complex is shown on Fig. 4.

As a result of those studies, it was concluded that Araneidae toxins, and JSTX-3, in particular, can form the chelating complexes with the prosthetic group of glutamate membrane receptors. This mechanism of toxins interaction with the glutamate receptors was confirmed in the experiments on the neuromuscular junction of lobster. The blocking characteristics of JSTX-3 significantly deteriorated with the addition of $\mathrm{Fe}^{3+}$ ions in the culture medium [74, 75, 97].

Thus, the results presented in our review demonstrated that the arthropods' toxins, both phenol and indole derivatives, may be useful in the laboratory experiments. The molecular weights and chemical structure of the most important toxins were studied until the end of 20th century [2, 36, 38-57]. Of practical significance might be three Araneidae toxins synthesized at that period: JSTX-3, NSTX-3, and the argiopin. Synthesis of JSTX-3 toxin and its four analogs with different polyamines' was conducted, and they all blocked the glutamate receptors [26]. A synthetic argiopin also possessed an ability to block the glutamate

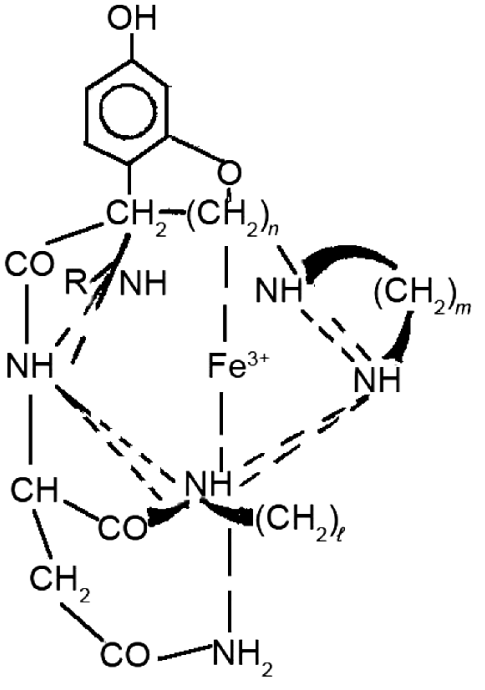

Fig. 4. Hypothetical structure of the chela ting complex of JSTX-3 with cation $\mathrm{Fe}^{3+}$ [97]

Рис. 4. Гіпотетична структура хелатного комплексу JSTX-3 з катіоном заліза $\mathrm{Fe}^{3+}[97]$ receptors [18].

Chemical structure of antagonists of the glutamatergic synapses isolated from the venoms of various Araneidae has several common features. All these aganists contain: 1 - aromatic group (phenolacetic or indolacetic), 2 - asparagine or modified lysine, 3 aliphatic polyamine of different lengths, 4 - many of them have $\mathrm{N}$-terminal arginine [5, $12,22,23,28]$.

The abovementioned toxins form two families depending on the aromatic groups which they contain. A family of phenolacetic acid derivatives contains the most widespread and investigated toxins - the argiopin $\left(\operatorname{argioxin}_{636}\right)$, JSTX-3, NSTX-3 [28]. The 
family of the indolylacetic acid derivatives is less studied and contains a number of toxins obtained from $A$. lobata (argiopinins, pseudoargiopinins), A. gemma, A. trifasciata and other Araneidae [12, 22, 23].

A study of toxins from $N$. clavata and $A$. lobata was carried out in Ukraine by a scientific team under a supervision of O.A. Krishtal [2, 36] (Fig. 5). As a result of their studies, they concluded that the 2,4-dihydroxyphenylacetate-asparagine fragments play a key role in toxin interaction with the glutamate CRC. These fragments are similar in all these antagonists and define their biological activity. The length and structure of polyamines define the individual differences in toxins' properties.

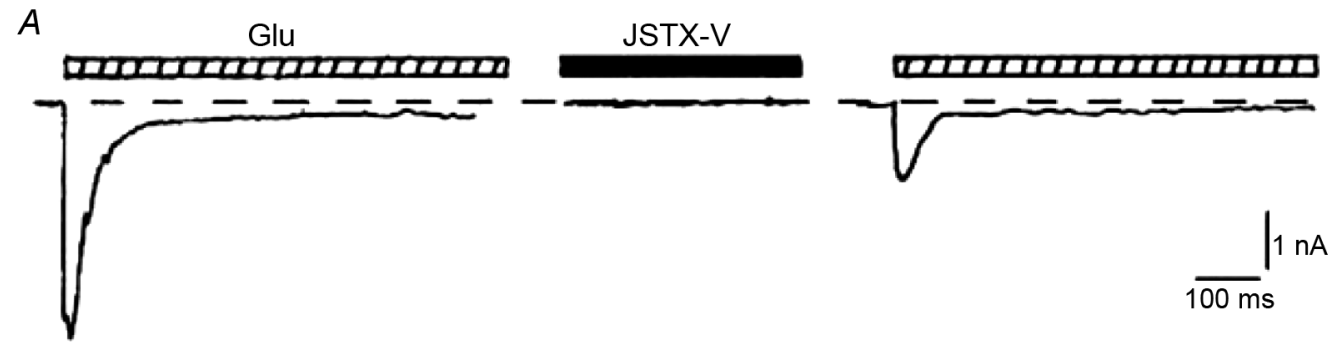

$B$

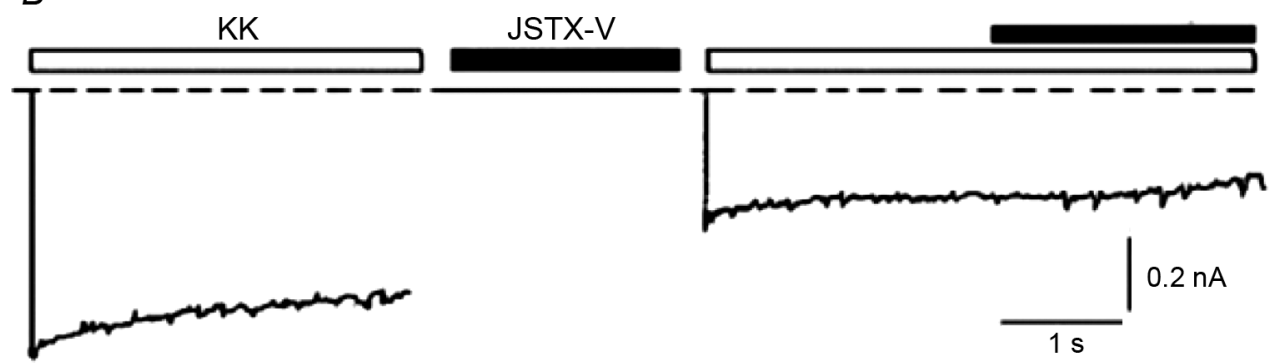

Fig. 5. The venom JSTX-V blocks chemo-activated transmembrane electrical currents in membrane of rat hippocampal pyramidal neuron: $A$ - influence on glutamate-activated (Glu) currents; $B$ - influence on kainat-activated $(\mathrm{KK})$ currents. After the registration of the control responses to Glu and KK, the membrane was maintained in Ringer solution with JSTX-V $\left(2.5 \times 10^{-4}\right.$ units/ $\left.\mu \mathrm{l}\right)$ during $3 \mathrm{~min}$. In this experiment, the amplitudes of chemo-activated currents decreased after the JSTX-V influence. Experiment with JSTX-V re-application in the same concentration $\left(2.5 \times 10^{-4}\right.$ units/ $\left.\mu \mathrm{l}\right)$ on the background of $\mathrm{KK}$ is shown on (B). Concentrations of Glu and KK were $1 \mathrm{mmol} / \mathrm{l}$. V hold - $100 \mathrm{mV}$ [42]

Рис. 5. Отрута JSTX-V блокує хемоактивовані трансмембранні електричні струми у мембранах пірамідних нейронів гіпокампу щура: $A$ - вплив на глутамат-активовані (Glu) струми; $B$ - вплив на каінат-активовані (KK) струми. Після реєстрації контрольних відповідей на Glu та KK мембрану витримували у розчині Рінгера з JSTX-V (2,5×10-4 од/мкл) протягом 3 хв. У цьому експерименті амплітуди хемо-активованих струмів зменшувалися після впливу JSTX-V. Експеримент із повторною аплікацією JSTX-V у тій же концентрації $\left(2,5 \times 10^{-4}\right.$ од/мкл) на тлі KK показано на $(B)$. Концентрації Glu та KK становили 1 ммоль/л. V підтр - 100 мB [42]

In those studies, it was found that JSTX-3 is a unique toxin among others from the point of view of a correlation between its chemical structure and the physiological effects, and the most simple structure is defining maximal effect [8]. The argiopin toxin also possesses unique properties among the toxins obtained from $A$. lobata, because of optimal correlation between its chemical structure and physiological effect [22, 23]. As a result of these studies, it was concluded that Araneidae toxins, and JSTX-3 in particular, can form 
the chelating complexes with the prosthetic group of the glutamate receptors in plasma membrane. This mechanism of toxins interaction with the glutamate receptors was studied also in experiments on a neuromuscular junction of the lobster. The blocking characteristics of JSTX-3 significantly deteriorated with the addition of $\mathrm{Fe}^{3+}$ ions to the cultural mixture $[74,75,82,97]$. Physiologically active toxic molecules with such chemical structures were also suggested to be used in biotechnology [41, 42].

\section{ACKNOWLEDGEMENTS}

The author is grateful to people with whom this long-continued research became possible: mother - prof. in entomology Z.F. Klyuchko (I.I. Schmalhausen Institute of Zoology of the National Academy of Science of Ukraine), and great teachers in neurophysiology - prof. O.A. Krishtal (A.A. Bogomoletz Institute of Physiology of the National Academy of Science of Ukraine) and prof. N. Akaike (Tokyo University, Japan), as well as the unforgettable colleagues A.Ya. Tzyndrenko and N.I. Kiskin

The author of this study confirms that the research and publication of the results were not associated with any conflicts regarding commercial or financial relations, relations with organizations and/or individuals who may have been related to the study, and interrelations of co-authors of the article.

1. Abe T., Miwa A. Effects of a spider toxin on the glutaminergic synapse of lobster muscle. J. Physiol., 1988; 389: 243-252.

[DOI: https://doi.org/10.1113/jphysiol.1983.sp014714; PMC1199159; PMID:6310085; Google Scholar]

2. Akaike N., Kawai N., Kiskin N.I., Kljuchko E.M., Krishtal O.A., Tsyndrenko A. Ya. Spider toxin blocks excitatory amino acid responses in isolated hippocampal pyramidal neurons. Neurosci. Lett., 1987; 79: 326-330.

[DOI: https://doi.org/10.1016/0304-3940(87)90453-8]

3. Akhunov A., Chernetsky I.I., Sadykov A.S. Biochemical characteristics of some arthropods venoms of Central Asia. Dokl. AN USSR, 1985; 285(4): 1009-1011. (In Russian)

4. Antonov S.M., Grishin E.V., Magazanik L.G., Shupliakov O.V., Vesselkin N.P., Volkova T.M. Argiopin blocks the glutamate responses and sensomotor transmission in motoneurones of isolated frog spinal cord. Neurosci. Lett., 1987; 83(1,2): 179-184.

[DOI: https://doi.org/10.1016/0304-3940(90)90541-G]

5. Aramaki Y., Yashuhara T., Higashijima T., Yoshioka M., Miwa A. Kawai N., Nakajima T. Chemical characterization of spider toxins JSTX and NSTX. Proc. Japan Academy, 1986; 62(9): 1012-1014. [DOI: https://doi.org/10.2183/pjab.62.359]

6. Ashe J.H., Cox C.L., Adams M.E. Argiotoxin 636 blocks excitatory synaptic transmission in rat hippocampal neurons. Brain Res., 1989; 480(1/2): 234-241.

[DOI: https://doi.org/10.1016/0006-8993(89)91587-4; PMID: 2540876; Google Scholar]

7. Atkinson P.K. Some studies or the oedematogenic action of the verom or funnel web spiders (Atrax species). Aust. J. Exp. Biol. Med. Sci., 1986; 64(5): 453-464. [DOI: https://doi.org/10.1038/icb.1986.48; Google Scholar]

8. Bateman A., Boden P., Dell A., Duce I.R., Quicke D.L., Usherwood P.N.R. Postsynaptic block of a glutaminergic synapse by low molecular weight fraction of spider venom. Brain Res., 1985; 339(2): 237-244.

[DOI: https://doi.org/10.1016/0006-8993(85)90088-5; Google Scholar]

9. Boden P., Bycroft B.W., Chabra S.R., Chiplin J., Crowley P.J., Grout R.J., King T.J., McDonald E., Rafferty P., Usherwood P.N.R. The action of natural and synthetic isomers of quisqualic acid at a well-defined glutamatergic synapse. Brain Res., 1986; 385(2): 205-211.

[DOI: https://doi.org/10.1016/0006-8993(86)91065-6; Google Scholar]

10. Bowers C., Phillips H.S., Lee P., Jan I.N., Jan L.Y. Identification and purification of an irreversible presynaptic neurotoxin from the venom of the spider Hololena curta . Proc. Natl. Acad. Sci. USA, 1987; 84(10): 8506-8510.

[DOI: https://doi.org/10.1073/pnas.84.10.3506; Google Scholar]

ISSN 1996-4536 (print) • ISSN 2311-0783 (on-line) • Біологічні Студії / Studia Biologica • 2019 • Том 13/№2 • С. 99-116 
11. Branton W.D., Kolton L., Jan I.N., Jan L.I. Neurotoxins from Plectreurus spider venom are potent presynaptic blockers in Drosophyla. J. Neurosci., 1987; 7(12): 4195-4200.

[DOI: https://doi.org/10.1523/JNEUROSCI.07-12-04195.1987; Google Scholar]

12. Budd T., Clinton P., Dell A., Duce I.R., Johnson S.J., Quicke D.L.J., Usherwood P.N.R., Usoh G. Isolation and characterisation of glutamate receptor antagonists from venoms of orb-web spiders. Brain Res., 1988; 448(2): 30-39.

[DOI: https://doi.org/10.1016/0006-8993(88)91098-0; Google Scholar]

13. Catterall $W$. Neurotoxins as allosteric modifiers of voltage-sensitive sodium channels. Adv Cytopharmacol., 1979; 3: 305-316.

[PMID: 474299; Google Scholar]

14. Cavalieri M., D'Urso I., Lassa A., Pierdominici E., Robello H., Grusso A. Characterisation and some properties of the venom gland extract of a theriid spider (Steatoda paukulliana) frequently mistaken for black widow spider (Latrodectus tredecimguttatus). Toxicon., 1987; 25(9): 965-974. [PMID: 3433306; Google Scholar]

15. Chanturia A.N., Mironov S.L., Sokolov Yu.V. The energy profile of the channel formed by latrotoxin in bilayer phospholipid membrane. Ukr. Biochem. Journal, 1986; 58(1): 48-56. (In Russian)

16. Chemistry and Pharmacology. The Alkaloids. Ed. G.A. Cordell, A. Brossi. USA: Academic Press, 1994. 280 p.

17. Early S.L., Michaelis E.K. Presence of protein and glutamate as major constituents of the venom of the spider Araneus gemma. Toxicon., 1987; 25(4): 433-442.

[PMID: 3617081; Google Scholar]

18. Elin E.A., Macedo V.F., Onoprienko V.V., Osokina N.E., Tikhomirova O.V. Synthesis of argiopin. Bioorg. Chemistry, 1988; 14(5): 704-706. (In Russian)

19. Friedel T., Nentwig $W$. Immobilising and lethal effects of spider venoms on the cockroach and the common mealbeetle. Toxicon., 1989; 27(3): 305-316.

[PMID: 2728023; Google Scholar]

20. Fortschritte der Chemie organischer Naturstoffe. In: Progress in the Chemistry of Organic Natural Products. Ed. W. Herz, G.W. Kirby, R.E. Moore, W. Steglich, Ch. Tamm. USA: Springer Science \& Business Media, 2012; 66. 332 p.

21. Gration K.A.F., Clark R.B., Usherwood P.N.R. Three types of glutamate receptor on junktional membrane of locust muscle fibers. Brain Res., 1979; 171(2): 360-364.

[DOI: https://doi.org/10.1016/0006-8993(79)90343-3; PMID: 223735; Google Scholar]

22. Grishin E.V., Volkova T.M., Arseniev A.S. Antagonists of glutamate receptors from the venom of Argiope lobata spider. Bioorganicheskaya Khimiya, 1988; 14(7): 883-892. (In Russian)

23. Grishin E.V., Volkova T.M. Arsenyev A.S., Reshetova O.S., Onoprienko V.V., Magazanik L.G., Antonov S.M., Fedorova I.M. Structural-functional characterization of argiopin-an ion channel blocker from the venom of spider Argiope lobata. Bioorg Khim., 1986; 12(8): 1121-1124. (In Russian) [PMID: 2430580]

24. Hagiwara K., Aramaki Y., Shimazaki K., Kawai N., Nakajima T. lodinated Joro toxin (JSTX-3). Its structure and binding to the lobster neuromuscular synapse. Chem Pharm Bull, 1988; 36(3): 1233-1236. [DOI: https://doi.org/10.1248/cpb.36.1233; PMID: 3409406; Google Scholar]

25. Halliwell J.V., Othman J.B., Pelchen-Matthews A., Dolly J. O. Central action of dendrotoxin: selective reduction of transient $\mathrm{K}$ conductance in hippocampus and binding to localized acceptors. PNAS, 1986; 83(2): 493-497.

[DOI: https://doi.org/10.1073/pnas.83.2.493; PMID:2417246; PMCID:PMC322886]

26. Hashimoto Y., Endo Y., Shudo K., Aramaki Y., Kawai N., Nakajima T. Synthesis of spider toxin JSTX-3 and its analogs. Tetrahedron Letters, 1987; 28(30): 3511-3514. [DOI: https://doi.org/10.1016/S0040-4039(00)96340-8; Google Scholar]

27. Himmelreih N.G., Pivneva T.A., Lishko V.K., Ivanov A.P. On the calcium permeability of latrotoxininduced synaptosomes. Ukr. Biochem. Journal, 1987; 59(2): 39-44. (In Russian)

28. Jackson H., Usherwood F.N.R. Spider toxins as tools for dissecting elements of excitatory amino acids transmission. Trends Neurosci., 1988; 11(6): 278-283.

[DOI: https://doi.org/10.1016/0166-2236(88)90112-9; PMID: 2465627; Google Scholar]

29. Jankovic J., Albanese A., Atassi M.Z., Dolly J.O., Hallett M., Mayer N.H. Botulinum Toxin E-Book: Therapeutic Clinical Practice and Science. USA: Elsevier Health Sciences, 2009. 512 p.

30. Kawai N., Miwa A., Abe T. Spider venom contains specific receptor blocker of glutaminergic synapses. Brain Res., 1982; 247(1): 169-171.

[DOI: https://doi.org/10.1016/0006-8993(82)91044-7; PMID: 6127145; Google Scholar]

ISSN 1996-4536 (print) • ISSN 2311-0783 (on-line) • Біологічні Студії / Studia Biologica • 2019 • Том 13/№2 • C. 99-116 
31. Kawai N., Miwa A., Abe T. Effect of spider toxin on glutaminergic synapses in the mammalian brain. Biomed. Res., 1982; 3(3): 353-355.

[DOI: https://doi.org/10.2220/biomedres.3.353; Google Scholar]

32. Kawai N., Miwa A., Abe T. Blood of glutamate receptors by a spider toxin. In: Maridel P., DeFendis F.V. (Ed.) From Molecular Pharmacology to Behavior. New York: Raven Press, 1983: 30-34. [PMID: 6314760; Google Scholar]

33. Kawai N., Yamagishi S., Saito M., Furuya K. Blockade of synaptic transmission in the squid giant synapse by a spider toxin (JSTX). Brain Res., 1983; 278(2): 346-349. [DOI: https://doi.org/10.1016/0006-8993(83)90269-X Google Scholar]

34. Kawai N., Miwa A., Saito M., Pan-How H., Yosioka M. Spider toxin (JSTX) action on the glutamate synapse. J. Physiol. (Paris), 1984; 79(4): 228-231.

35. Kerry C.J., Ramsey R.L., Sansom M.S.P., Usherwood P.N.R. Single channel studies of non-comretitive antagonism of a quisqualate sensitive glutamate receptor by argiotoxin 636 - a fraction isolated from orb-web spider venom. Brain Res., 1988; 459(2): 312-327.

36. Kiskin N.I., Klyuchko E.M., Kryshtal O.A., Tsyndrenko A. Ya., Akaike N., Kawai N. Blocking action of Nephila clavata spider toxin on ionic currents activated by glutamate and its agonists in isolated hippocampal neurons. Neurophysiology, 1989; 21(2): 110-116. (In Russian) [PMID: 2474133; Google Scholar]

37. Kits K.S., Pick T. Action of the polyamine b-philantotoxin on neuromuscular transmission in insects. Neuropharm., 1986; 25(10): 1089-1093.

[DOI: https://doi.org/10.1016/0028-3908(86)90155-3; PMID: 2431342; Google Scholar]

38. Klyuchko O.M. Information and computer technologies in biology and medicine. Kyiv: NAUdruk, 2008. 252 p. (In Ukrainian)

39. Klyuchko O.M., Klyuchko Z.F. Electronic databases of Arthropods: methods and applications. Biotechnologia Acta, 2018: 11(4); 28-49. [DOI: https://doi.org/10.15407/biotech11.04.028; Google Scholar]

40. Klyuchko O.M. Investigation of chemical substances of terrestrial arthropods. Studia Biologica, 2019: 13(1); 129-144.

[DOI: https://doi.org/10.30970/sbi.1301.594; Google Scholar]

41. Klyuchko O.M. Electronic expert systems for biology and medicine. Biotechnologia Acta, 2018; 11(6): 5-28.

[DOI: https://doi.org/10.15407/biotech11.06.005; Google Scholar]

42. Klyuchko O.M. Biotechnical information systems for monitoring of chemicals in environment: biophysical approach. Biotechnologia Acta, 2019; 12(1): 5-28.

[DOI: https://doi.org/10.15407/biotech12.01.005; Google Scholar]

43. Klyuchko O.M. Method for monitoring of chemicals influence on bioorganisms in few time intervals. Patent UA 134575 U; G01N33/00, C12N 15/00, A61P 39/00. Priority: 14.12.2018, u201812443, Issued: 27.05.2019, Bull. 10, 12 p. (In Ukrainian)

44. Klyuchko O.M., Biletsky A. Ya., Lizunov G.V., Shutko V.N. Method for application of the system of large-scale monitoring of bioobjects with possibility of their radar control. Patent UA $134576 \mathrm{U}$; МПК G01N33/00, A61B 5/05, G01N 33/50, C12Q 1/02, G01S 13/00. Priority: 14.12.2018, u201812444, Issued: 27.05.2019, Bull. 10, 16 p. (In Ukrainian)

45. Klyuchko O.M. Method of application of biotechnical monitoring system for bioindicators' accounting with biosensor and sub-system for optical registration. - Patent UA 129987 U, G01N33/00, C12Q 1/02, C12N 15/00. Priority: 27.04.2018, u201804662, Issued: 26.11.2018, Bull. 22, 11 p. (In Ukrainian)

46. Klyuchko O.M. Method of cells' dissociation. - Patent UA 130672 U, G01N 33/00, C12Q 1/02, C12N 15/00. Priority: 27.04.18, u201804668, Issued: 26.12.2018, Bull. 24, 7p. (In Ukrainian)

47. Klyuchko O.M. Method of qualitative analysis of chemical substances. Patent UA $131016 \mathrm{U}$, G01N33/50, G01N21/78, C12Q 1/60. Priority: 11.05.2018, u201805174, Issued: 10.01.2019, Bull. 1, 9 p. (In Ukrainian)

48. Klyuchko O.M.. Method for monitoring of chemicals influence on bioorganisms in few time intervals. Patent UA 134575 U; G01N33/00, C12N 15/00, A61P 39/00. Priority: 14.12.2018, u201812443, Issued: 27.05.2019, Bull. 10, 10 p. (In Ukrainian)

49. Klyuchko O.M., Biletsky A. Ya., Lizunov G.V., Shutko V.N. Method of electrical signals generating by bio-elements in technical hybrid system. Patent UA 134574 U; A01N 1/02, G01N 33/00, A61N 1/32, B82Y 30/00. Priority: 14.12.2018, u201812442, - Issued: 27.05.2019, Bull. 10, 10 p. (In Ukrainian)

50. Klyuchko O.M., Biletsky A.Ya., Lizunov G.V., Shutko V.N. Method for application of the system of large-scale monitoring of bioobjects with possibility of their radar control. Patent UA 134576 U; МПК

ISSN 1996-4536 (print) • ISSN 2311-0783 (on-line) • Біологічні Студії / Studia Biologica • 2019 • Том 13/№2 • C. 99-116 
G01N33/00, A61B 5/05, G01N 33/50, C12Q 1/02, G01S 13/00. Priority: 14.12.2018, u201812444, Issued: 27.05.2019, Bull. 10, 1 p. (In Ukrainian)

51. Klyuchko O.M., Biletsky A. Ya., Navrotskyi D.O. Method of bio-sensor test system application. - Patent UA 129923 U, G01N33/00, G01N33/50, C12Q 1/02. Priority: 22.03.2018, u201802896, Issued: 26.11.2018, Bull. 22, 7 p. (In Ukrainian)

52. Klyuchko O.M., Biletsky A.Ya., Navrotskyi D.O. Method of application of biotechnical monitoring system with biosensor (biosensor test system). - Patent UA 132245 U; G01N33/00. Priority: 23.03.2018 u201802893, Issued: 25.02.2014, Bull. 4, 7 p. (In Ukrainian)

53. Klyuchko O.M., Biletsky A. Ya., Navrotskyi D.O. Method of application of biotechnical monitoring system with biosensor and sub-system for optical registration. - Patent UA $129922 \mathrm{U}, \mathrm{G} 01$ N33/50. Priority: 22.03.2018, u201802894, Issued: 26.11.2018, Bull. 22, 10 p. (In Ukrainian)

54. Klyuchko O.M., Biletsky A.Ya., Navrotskyi D. Method of application of biotechnical monitoring system with expert subsystem and biosensor. Patent UA 131863 U; G01N33/00, C12Q 1/02, C12N 15/00. Priority: 27.04.18, u201804663, Issued: 11.02.2019, Bull. 3, 7 p. (In Ukrainian)

55. Klyuchko O.M., Biletsky A.Ya., Navrotskyi D.A. Method of quantitative analysis of chemical substances. Patent UA 131524 U; G01N33/50, G01N21/78, C12Q 1/60G01N33/50, G01N21/78, C12Q 1/60. Priority: 11.05.2018, u201805175, Issued: 25.01.2019, Bull. 2, 10 p. (In Ukrainian)

56. Klyuchko O.M., Biletsky A.Ya. Method of qualitative analysis of hydrocarbons with harmful and toxic effect on bioobjects. Patent UA 133676 U; G01N 33/50, G01N 21/78. Priority: 06.06.2018, u201806342, Issued: 25.04.2019, Bull. 8, 10 p. (In Ukrainian)

57. Klyuchko O.M., Biletsky A. Ya. Method of qualitative analysis of chemical substances for the influence on electrical currents in bioobjects. Patent UA134142 U; G01N 33/50, G01N 21/78, C12Q 1/60. Priority: 06.06.2019, u201806345, Issued: 10.05.2019, Bull. 9, 10 p. (In Ukrainian)

58. Kostyuk P.G., Kryshtal O.A. Mechanisms of electrical excitability of the nerve cell. M: Nauka, 1981. 208 p. (In Russian)

59. Kusano Tomonobu, Suzuki Hideyuki. Polyamines: A Universal Molecular Nexus for Growth, Survival, and Specialized Metabolism.USA: Springer, 2015. 336 p.

60. Lee C.Y. Resent advances in chemistry and pharmacology of snake toxins. In: Advances in Cytophormacology. New York: Raven Press, 1979: 1-16.

61. Magazanik L.G., Antonov S.M., Gmiro V.E. Mechanisms of activation and blocking of the postsynaptic membrane sensitive to glutamate. Biological Membranes, 1984; 1(2): 130-140. (In Russian)

62. Magazanik L.G., Antonov S.M., Fedorova I.M., Grishin E.V. The action of Agriope lobata spider venom and its low molecular weight component - argiopin on postsynaptic membranes. Biological Membranes, 1986; 3(12): 1204-1219. (In Russian)

63. Magura I.S. Problems of electrical excitability of neuronal membrane. Kyiv: Naukova Dumka, 1981. 208 p. (In Russian)

64. Martin M.F., Rochad H. Large scale purification of toxins from the venom of the scorpion Androctonus australis Hector. Toxicon, 1986; 24(11-12): 1131-1139.

[DOI: https://doi.org/10.1016/0041-0101(86)90139-X; Google Scholar]

65. Martin M.F., Rochat H., Marchot P., Bougis P.E. Use of high performance liquid chromatography to demonstrate quantitative variation in components of venom from the scorpion Androctonus australis Hector. Toxicon, 1987; 25(5): 569-573.

[DOI; https://doi.org/10.1016/0041-0101(87)90293-5; Google Scholar]

66. Matsuoka I., Syuto B., Kurinara K., Kubo S. Cytotoxic action of Clostridium botulinum type C, toxin on neurons of central nervus system in dissociated culture. Jap. J. Med. Sci. Biol., 1986; 39(5-6): 247. [DOI: https://doi.org/10.1016/0041-0101(87)90293-5; Google Scholar]

67. Michaelis E.K., Michaelis M.L., Stormann T.M., Chittenden W.L., Grubbs R.D. Purification and molecular characterization of the brain synaptic membrane glutamate-binding protein. J. Neurochem., 1983; 30: 1742-1747.

[DOI: https://doi.org/10.1111/j.1471-4159.1983.tb08150.x; Google Scholar]

68. Michaelis E.K., Galton N., Early S.L. Spider venoms inhibit L-glutamate binding to brain synaptic menbrane receptors. Proc. Natl. Acad. Sci. USA, 1984; 81: 5571-5574.

[DOI: https://doi.org/10.1073/pnas.81.17.5571; Google Scholar]

69. Miwa A., Kawai N. Presynaptic glutamate receptor - possible involvement of $\mathrm{K}$ channel. Brain Res., 1986; 385(1): 161-64.

[DOI: https://doi.org/10.1016/0041-0101(87)90293-5; Google Scholar]

70. Miwa A., Kawai N., Saito M., Pan-Hou H., Yosioka M. Effect of spider toxin (JSTX) on excitatory postsynaptic current at neuromuscular synapse of spiny lobster. J. Neurophys., 1987; 58(2): 216-220. [DOI: https://doi.org/10.1152/jn.1987.58.2.319; Google Scholar]

ISSN 1996-4536 (print) • ISSN 2311-0783 (on-line) • Біологічні Студії / Studia Biologica • 2019 • Том 13/№2 • C. 99-116 
71. Miwa A., Kawai N., Ui M. Pertussis toxin blocks presynaptic glutamate receptor - a novel "glutamate" receptor in lobster neuromuscular synapse. Brain Res., 1987; 416(1): 162-165.

[DOI: https://doi.org/10.1016/0006-8993(87)91510-1; Google Scholar]

72. Mylecharane E.J., Spence I., Sheumack D.D., Claassens R., Howden M.E.M. Action of robustoxin, a neurotoxic polypeptide from the venom of the male funnel-web spider (Atrax robustus) in anaesthetized monkeys. Toxicon, 1989; 24(4): 481-492.

[DOI: https://doi.org/10.1016/0041-0101(89)90211-0; Google Scholar]

73. Narahashi T. Modulation of neurve membrane sodium channe1s by neurotoxins. In: Advances in Cytopharmacology. New York: Raven Press, 1979: 293-304.

74. Pan-Hou H., Suda Y. Molecular action mechanism of spider toxin on glutamate receptor: role of 2,4-dihydroxyphenylacetic acid in toxin molecule. Brain Res., 1987; 418(1): 198-200.

[DOI: https://doi.org/10.1016/0006-8993(87)90981-4; Google Scholar]

75. Pan-Hou H., Suda Y., Sumi M., Yoshioka M., Kawai N. Inhibitory effect of 2,4-dihydroxyphenylacetylasparagine, a common moiety of spider toxins on glutamate binding to rat brain synaptic membranes. Neurosci. Lett., 1987; 81: 199-203.

[DOI: https://doi.org/10.1016/0304-3940(87)90365-X; Google Scholar]

76. Pan-Hou H., Suda Y., Sumi M., Yoshioka M., Kawai N. A spider toxin (JSTX) inhibits L-glutanate uptake by rat brain synaptosomes. Brain Res., 1989; 476(2): 354-357.

[DOI: https://doi.org/10.1016/0006-8993(89)91258-4; Google Scholar]

77. Piek T. Insect venoms and toxins. In: Kerkut G. A. (Ed.) Comprehensive Insect Physiology, Biochemistry and Pharmacology. Oxford: Pergamon Press, 1987; 11: 595-635.

[DOI: https://doi.org/10.1017/S1742758400006755; Google Scholar]

78. Saito M., Kawai N., Miwa A., Pan-Hou H., Yoshioka M. Spider toxin (JSTX) blocks glutamate synapse in hippocampal pyramidal neurons. Brain Res., 1985; 346(2): 397-399.

[DOI: https://doi.org/10.1016/0006-8993(85)90878-9; Google Scholar]

79. Schmidt J., Blum M.S., Overal W.L. Comparative ensymology of venoms from stringing Hymenoptera. Toxicon, 1986; 24(9): 207-291.

[DOI: https://doi.org/10.1016/0041-0101(86)90091-7]

80. Shuplyakov O.V., Antonov S.M., Veselkin N.P., Magazanik L.G. The ability of argiopin to block glutamatergic synapses in the frog spinal cord. Zhurnal Evoliycion. Biohimii i Fiziologii, 1982; 23(2): 275-276.

[DOI: https://doi.org/10.1016/0041-0101(86)90091-7; Google Scholar]

81. Skock V.I., Selianko A.A., Derckach V.A. Neuronal cholynoreceptors. M.: Nauka, 1987. 343 p. (In Russian) [DOI: https://doi.org/10.30970/sbi.1301.594]

82. Soloway S., Wilen S.H. Improved ferric chloride test for phenols. Anal. Chem., 1952; 24(6): 979-983.

83. Tashmuhamedov B.A. Ion transport through biological membranes and the mechanism of physiologically active substances action. M: Nauka, 1985. 121p. (In Russian)

84. Tashmuchamedov B.A., Makhmudova E.M., Usmanov P.B., Kazakov I. Reconstitution in bilayer lipid membranes of the Crab Potamon Transcaspicum spider venom sensitive glutamate receptors. Gen. Physiol. Biophys., 1985; 4(6): 625-630.

85. Tashmuchamedov B.A., Makhmudova E.M., Usmanov P.B., Kazakov I., Atakuziev B.U. Isolation and reconstruction of glutamate receptors of insects on bilayer membranes. Uzbek. Biological Journal, 1983; 6: 57-58. (In Russian)

86. Tashmuchamedov B.A., Usmanov P.B., Kazakov I., Kalikulov D., Yukelson L. Ya., Atakusiev B.U. Effects of different spider venoms on artificial and biological membranes. In: Hucho F., Ovchinnicov Y.A. (Ed.) Toxins as Tools in Neurochemistry. Berlin: Walter de Gruyter, 1983: 311-323.

87. Teshima T., Wakamiya T., Aramaki Y., Nakajima T., Kawai N., Shiba T. Synthesis of a new neurotoxin NSTX-3 of Papua New Guinean spider. Tetrah. Lett., 1987; 28(30): 3509-3510. [DOI: https://doi.org/10.1016/S0040-4039(00)96339-1]

88. Tibballs J., Sutherland S. K., Duncan A.W. Effects of male Sydney funnel-web spider venom in a dog and cat. Austr. Vet. J., 1987; 64(2): 63-64. [DOI: https://doi.org/10.1111/j.1751-0813.1987.tb16137.x; PMID: 3606512]

89. Tuychibaev M.U., Tashmuchamedov B.A., Magazanik L.G. New neurotoxin from the venom of the great hornet Vespa orientalis. Uzbek. Biological Journal, 1983; 6: 3-4. (In Russian)

90. Ushkarev Yu.A., Grishin E.V. Karakurt neurotoxin and its interaction with the rat brain receptors. Bioorg. Chemistry, 1986; 12(1): 71-81. (In Russian).

91. Usmanov P.B., Kalikulov D., Shadyeva N., Tashmuchamedov B.A. Action of Agriope lobata spider venom on glutamate and cholineric synapses. Dokl. AN USSR, 1983; 273(4): 1017-18. (In Russian)

ISSN 1996-4536 (print) • ISSN 2311-0783 (on-line) • Біологічні Студії / Studia Biologica • 2019 • Том 13/№2 • С. 99-116 
92. Usmanov P.B., Kalikulov D., Nasledov G.A., Tashmuchamedov B.A. Effect of Segestria florentina spider venom on the mechanism of inactivation of sodium channels. Biophysics, 1985; 30(4): 617-619. (In Russian)

93. Usmanov P.B., Kalikulov D., Shadyeva N.G., Nenilin A.B., Tashmuchamedov B.A. Postsynaptic blocking of glutamatergic and cholinergic synapses as a common property of Araneidae spider venoms. Toxicon, 1985; 23(3): 528-531.

[PMID: 2992124]

94. Usmanov P.B., Tonkikh A.K., Shadyeva H., Sadykov A.A., Tashmuchamedov B.A. Effect of Agriope lobata spider venom and its components on the binding of $\mathrm{L} 1 \mathrm{H} 1$ glutamate to locust muscle membranes. Ukr. Biochem. Journal, 1988; 60(3): 78-81. (In Russian)

[PMID: 2901152]

95. Vyklický L.Jr., Krůsek J., Vyklický L., Vyskocil F. Spider venom of Araneus opens and desensitizes glutamate channels in chick spinal cord neurones. Neurosci. Lett., 1986; 68: 227-231. [DOI: https://doi.org 10.1016/0304-3940(86)90147-3; PMID: 2427975]

96. Zlotkin E. Toxins derived from Arthropod venoms specially affecting insects. In: Kerkut G.A., Gilbert L.I. (Ed.) Comprehensive Insect Physiology, Biochemistry and Pharmacology. Oxford: Pergamon Press, 1985; 10: 499-546.

97. Yoshioka M., Narai N., Pan-Hou H., Shimazaki K., Miwa A., Kawai N. Color development upon reaction of ferric ion with the toxin JSTX, a glutamate receptor blocker present in the venom gland of the spider Nephila clavata (Joro spider). Toxicon, 1988; 26(4): 414-416.

[DOI: https://doi.org/10.1016/0041-0101(88)90011-6]

\title{
БІОЛОГІЧНОАКТИВНІ ПОХІДНІ ФЕНОЛУ Й ІНДОЛУ НАЗЕМНИХ ЧЛЕНИСТОНОГИХ: ЕЛЕКТРОФІЗІОЛОГІЧНІ ТА ХІМІЧНІ ВЛАСТИВОСТІ
}

\author{
О. М. Ключко \\ Інститут експериментальної патології, \\ онкології та радіобіології ім. Р. Є. Кавецького НАН України, Київ \\ вул. Васильківська, 45, Київ 03022, Україна \\ e-mail: kelenaXX@ukr.net
}

Токсини-антагоністи глутаматергічних синапсів були виявлені в отрутах різних наземних членистоногих - як комах, так і павуків. Відома хімічна структура деяких із них, більшість $€$ похідними фенолу й індолу. Їх успішно застосовують для електрофрізіологічних досліджень мембранних структур, і цей огляд присвячено деяким результатам досліджень таких речовин, що можуть бути корисними для лабораторної практики. У публікації описано експериментальні дослідження хімічних структур паралельно із результатами електрофрізіологічної реєстрації ефектів, які спричиняють отрути і токсини деяких членистоногих. Запропоновано пояснення фрізіологічної дії речовин-антагоністів глутаматних рецепторів залежно від особливостей їхньої хімічної будови. Обговорено роль різних фрагментів молекул токсинів у блокуванні глутаматних рецепторів. Також наведено інформацію щодо компонентів отрут комах родин Sphecidae (Philanthus triangulum) і Araneidae, а саме кількох видів павуків із родів Argiope, Araneus, Nephila.

Ключові слова: отрути членистоногих, токсини, антагоністи рецепторів, трансмембранний електричний струм

Одержано: 26.06.2019

ISSN 1996-4536 (print) • ISSN 2311-0783 (on-line) • Біологічні Студії / Studia Biologica • 2019 • Том 13/№2 • C. 99-116 